\title{
Sustainable Management for Arsenic (As) Free Safe Drinking Water in Bangladesh: A Review
}

Kamonasish Das, Dhiman Roy and Mostafa MG*

Institute of Environmental Science, University of Rajshahi, Rajshahi-6205, Bangladesh

\begin{abstract}
The presence of elevated levels of naturally occurring arsenic in groundwater of Bangladesh has severely impaired the decade long effort of providing safe water to its population. Most of the recognized stages of arsenic poisoning have been identified in Bangladesh and the risk of arsenic poisoning in the population is increasing every day. The severity of arsenic contamination is demanding extensive research in this field. Many studies have been carried out in Bangladesh, West Bengal in India and other countries as well, but the situation is still out of sound control. In order to minimize arsenic exposure, a work to provide various alternate safe drinking water options to the exposed population has been initiated. This article implies to look at the sustainable management for safe drinking water in Bangladesh by reviewing different measures to remedy the arsenic contamination in groundwater.
\end{abstract}

Keywords: Groundwater; Drinking water; Household; Sustainable

\section{Introduction}

Ground water arsenic contamination in Bangladesh poses the most drastic mass poisoning in history [1,2]. Chronic ingestion of inorganic arsenic has adverse effects on human health, it even causes cancer. High level of Arsenic contamination in the ground water of Bangladesh first identified at 1993 [3-7]. This has resulted in a severe environmental disaster affecting several million people in the region, as groundwater is the main source of potable water for nearly $98 \%$ of the population in Bangladesh. What was a success story is now poised to threaten the lives of millions of people living in 61 out of the 64 districts in Bangladesh (Figure 1).

However, four years ahead, at 2011 Bangladesh achieve the MDG

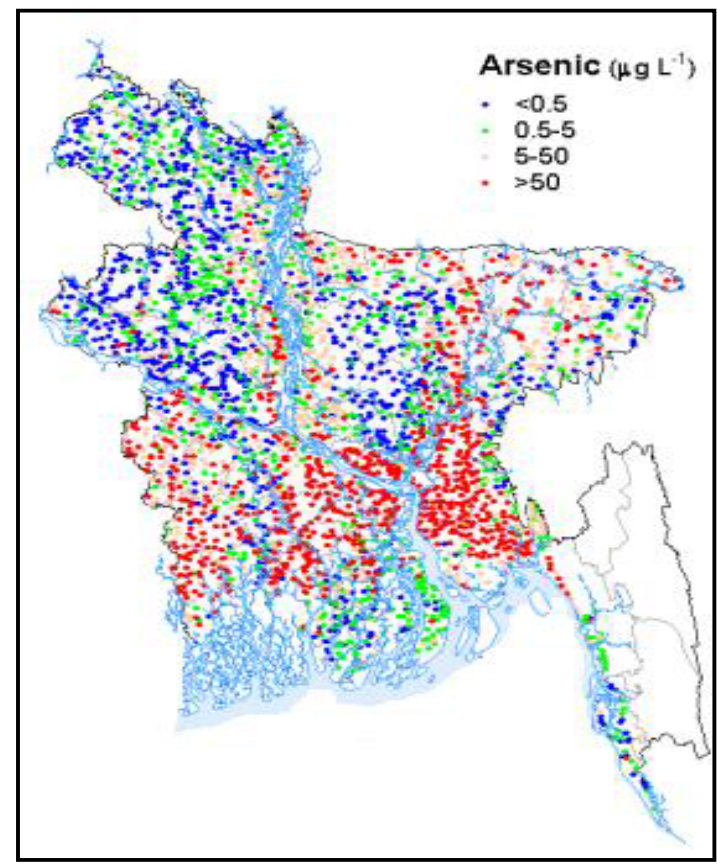

Figure 1: Distribution of Arsenic in Bangladesh. drinking water target with a nationwide coverage. At the same time as the most densely populate country of the world with more than 160 million population still $19 \%$ of the population use unsafe drinking water. Moreover, in terms of planning, monitoring and evaluation of safe drinking water programs Bangladesh scored 0.5 out of 1 in the latest report of UN-Water Global Analysis and Assessment of Sanitation and Drinking-Water (GLAAS). This report of also stated that no national assessment was done for safe drinking water programs and status. Nevertheless, full donor funded programs of safe drinking water only $50 \%$ of official donor capital commitments utilized. Therefore, the question arises about sustainability of safe drinking water programs to achieve the nationwide coverage of safe drinking water for all the population of Bangladesh. This article implies to look at the sustainable management for safe drinking water in Bangladesh.

The study was conduct by reviewing the existing literature on arsenic mitigation and sustainable management of Bangladesh. To obtain available literature electronic database mainly PubMed, EBSCO was search with different key words. Furthermore, leading organization of water resource management organization, health organization like International Water Resources Association (IWRA), World Health Organization (WHO), The United Nations Children's Fund (UNICEF) - their website was searched for their policy paper, past and current project on drinking water and arsenic mitigation. And lastly but most importantly policy, strategy and evaluation research paper of Govt. of Bangladesh was reviewed for this article.

\section{Drinking Water Sources and Supply}

Recent national representative survey state that tube wells/tap water are the most common source of drinking water in both urban

*Corresponding author: Mostafa MG, Institute of Environmental Science, University of Rajshahi, Rajshahi-6205, Bangladesh, Tel:88072175004; E-mail: mostafa_ies@yahoo.com

Received April 29, 2015; Accepted May 20, 2015; Published May 26, 2015

Citation: Das K, Roy D, Mostafa MG (2015) Sustainable Management for Arsenic (As) Free Safe Drinking Water in Bangladesh: A Review. J Pet Environ Biotechnol 6: 228. doi:10.4172/2157-7463.1000228

Copyright: (c) 2015 Das K. This is an open-access article distributed under the terms of the Creative Commons Attribution License, which permits unrestricted use, distribution, and reproduction in any medium, provided the original author and source are credited. 
and rural areas. Nationally $94.4 \%$ household use taps or tube well water as drinking water. In rural areas, the rate was $95 \%$, which is marginally higher than in urban areas (93.2\%) [8]. Table 1 demonstrate the updated details of Major sources of drinking water of people of Bangladesh.

Presently national scenario of major sources of drinking water, different remedial measures of drinking water and arsenic status in household are presented. Commonly used drinking water treatment processes are presented in Table 2.

Although the estimates for contamination vary, between 77 and 95 million people in Bangladesh are affected by high levels of arsenic in their drinking water. The problem is not uniformly distributed, but the local hot spots are densely populated. It is interesting to note that one tube well can have $50 \mathrm{ppb}$ and a tube well less than 100 feet away can have $170 \mathrm{ppb}$. In all, 16 percent of the deep tube wells in Bangladesh and India are contaminated.

The water starts to become turbid through a process of oxidization and self-attenuation. The origin and distribution of arsenic in groundwater is still under study. However, early indications show that a biogeochemical reduction process mobilize the arsenic in the ground into a form that is present in water. Current theory suggests that an anaerobic bacterium is consuming iron and organic matter present in the young geological formation; it is then using the iodine present in soil to convert and dislodge the stable form of arsenic into an unstable form called arsenite. Arsenite, the most toxic form of arsenic, is now in solution and contaminates the wells. Current scenarios of contamination of Arsenic in household drinking water are presented in Table 3.

At 2006 Government of Bangladesh and UNICEF conducted a nationwide Arsenic testing program and reveled that around $20 \%$ of the tubewell identified with Arsenic contamination higher that national level, it is worth to mention here while internationally minimum acceptance level of Arsenic is $0.01 \mathrm{~g} / \mathrm{L}$ in Bangladesh it is $.05 \mathrm{~g} / \mathrm{L}$. The WHO/UNICEF Joint Monitoring Programme for Water Supply and Sanitation (JMP) has subtracted 20 percent of those relying on shallow wells from the coverage estimates of each of the surveys

\begin{tabular}{|c|c|c|c|c|}
\hline $\begin{array}{c}\text { Source of } \\
\text { Drinking water }\end{array}$ & $\begin{array}{c}\text { Urban } \\
\mathbf{( \% )}\end{array}$ & $\begin{array}{c}\text { Rural } \\
\mathbf{( \% )}\end{array}$ & $\begin{array}{c}\text { Total } \\
\mathbf{( \% )}\end{array}$ & Reference \\
\hline Tap/Tube well & 93.2 & 95.0 & 94.4 & {$[6]$} \\
\hline Well & 1.6 & 2.0 & 1.8 & {$[54]$} \\
\hline Pond/Ditch & 3.4 & 1.9 & 2.4 & {$[6]$} \\
\hline River/Canal & 0.9 & 0.3 & 0.5 & {$[43]$} \\
\hline Fountain & 0.1 & 0.7 & 0.5 & {$[43]$} \\
\hline Bottle water & 0.7 & 0.1 & 0.3 & {$[6]$} \\
\hline Total & 100.0 & 100.0 & 100.0 & \\
\hline
\end{tabular}

\begin{tabular}{|c|c|c|c|c|}
\hline Treatment & $\begin{array}{c}\text { Urban } \\
(\%)\end{array}$ & $\begin{array}{c}\text { Rural } \\
\mathbf{( \% )}\end{array}$ & $\begin{array}{c}\text { Total } \\
(\mathbf{\%})\end{array}$ & Reference \\
\hline Boiling & 4.6 & 3.6 & 3.9 & {$[6]$} \\
\hline $\begin{array}{c}\text { Use water purifying } \\
\text { tablet }\end{array}$ & 0.1 & 0.0 & 0.0 & {$[6]$} \\
\hline Use Fitkeri & 0.3 & 0.2 & 0.2 & {$[54]$} \\
\hline By filter & 0.8 & 0.3 & 0.4 & {$[6]$} \\
\hline Don't purify & 1.0 & 1.0 & 1.0 & {$[43]$} \\
\hline $\begin{array}{c}\text { Tap/Tube well water so } \\
\text { don't boil }\end{array}$ & 93.2 & 95.0 & 94.4 & {$[43]$} \\
\hline Total & 100.0 & 100.0 & 100.0 & \\
\hline
\end{tabular}

Table 2: Commonly used drinking water treatment processes.

\begin{tabular}{|c|c|c|c|c|}
\hline Status & Urban (\%) & Rural (\%) & Total (\%) & Reference \\
\hline Arsenic free & 75.5 & 75.0 & 75.1 & {$[6]$} \\
\hline $\begin{array}{c}\text { Arsenic } \\
\text { Contaminated }\end{array}$ & 11.7 & 9.4 & 10.1 & {$[43]$} \\
\hline Not detected yet & 12.8 & 15.6 & 14.8 & {$[54]$} \\
\hline Total & 100.0 & 100.0 & 100.0 & \\
\hline
\end{tabular}

Table 3: Arsenic status in household drinking water.

on file. Bangladesh is to only country for which the JMP has made an adjustment of the drinking water coverage estimates based on an actual water quality parameter. To allow for international comparability of estimates, JMP uses the following classification to differentiate between "improved" and "unimproved" drinking-water sources [9]. According to this classification in Bangladesh "improved" and "unimproved" drinking-water sources are as Table 4.

At present, although As contamination in the ground water of Bangladesh has been taken into account by the Government of Bangladesh, non-governmental organizations (NGOs) and donors are working together to address this critical issue - it is only being of a priority after 1998 while the contamination of high level of As detected at early 1990. A report of a join technical group of British Geological Survey (BGS), and Department of Public Health and Engineering (Bangladesh) suggest that ground water arsenic contamination in Bangladesh five major challenges, these are stated as follows [10]:

- "Test all tube wells for arsenic; there are about 8-10 million such wells in Bangladesh

- Investigate the mechanisms of arsenic contamination of groundwater

- Identify people with elevated risk of arsenic toxicity. A variety of toxic effects, including different types of cancers (most of which are not likely to be reversible)

- Provide alternative arsenic-safe water options which are culturally acceptable, technically feasible, environmentally safe, and affordable by common people

- Research into the extent of soils contamination due to irrigation with arsenic"

\section{Status of Safe Drinking Water}

Below, Figures 2, 3 and 4 are graphically presented the change of status of safe drinking water in Bangladesh from 1990 to 2010. Nationally Bangladesh has improved in terms of safe drinking water - piped on premises increased and other improvement occurred. However, in urban area total improvement has been fall in last two decades with fall in piped in premises percentage (Figure 2). This quite unusual finding might be explained by rapid urbanization and growth of newer slams which remain out focus; also it might be contribution of different natural disasters that inflated the population shifting from rural to urban; and also the political unrest which cause the out of focus where actual focus is needed.

Installation and assessment of safe water options were major activities of the mitigation component. Obviously, arsenic free water is the main way to reduce the risk of arsenic toxicity [11-13].

Attaching top priority to the problem of arsenic in drinking water, the Government of Bangladesh adopted the National Policy for Arsenic Mitigation 2004 (NPAM) and Implementation Plan for Arsenic Mitigation in Bangladesh (IPAM 2004). The policy provided guidelines 


\begin{tabular}{|c|c|}
\hline Improved drinking water & Unimproved drinking water \\
\hline $\begin{array}{l}\text { Use of } \\
\text { - Piped water into dwelling, plot } \\
\text { or yard } \\
\text { - Piped water into neighbor's plot } \\
\text { - Public tap/standpipe } \\
\text { - } \text { Pube well/borehole } \\
\text { - Protected dug well } \\
\text { - } \text { Rainwater spring }\end{array}$ & $\begin{array}{l}\text { Use of } \\
\text { - Unprotected dug well } \\
\text { - Unprotected spring } \\
\text { - Small cart with tank/drum } \\
\text { - Tanker truck } \\
\text { - Surface water (river, dam, lake, pond, } \\
\text { stream, channel, irrigation channel) } \\
\text { - Bottled water }\end{array}$ \\
\hline
\end{tabular}

Table 4: Improved and unimproved drinking water sources.

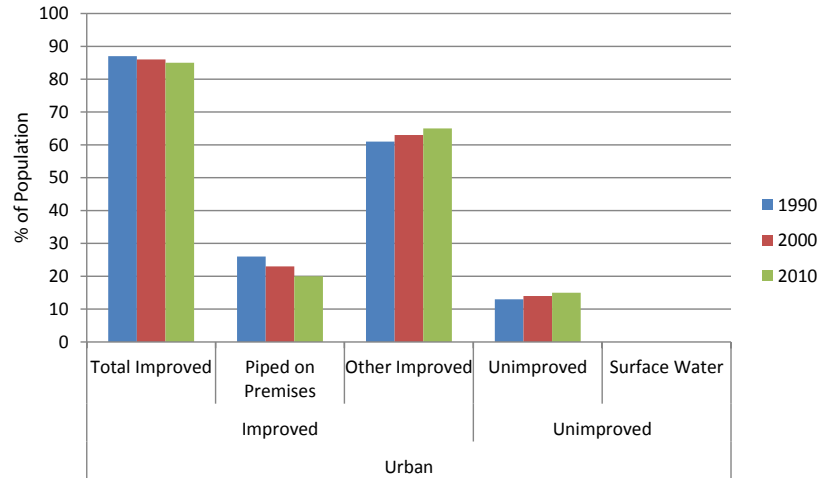

Figure 2: Status of safe drinking water from 1990 to 2010 in urban area of Bangladesh.

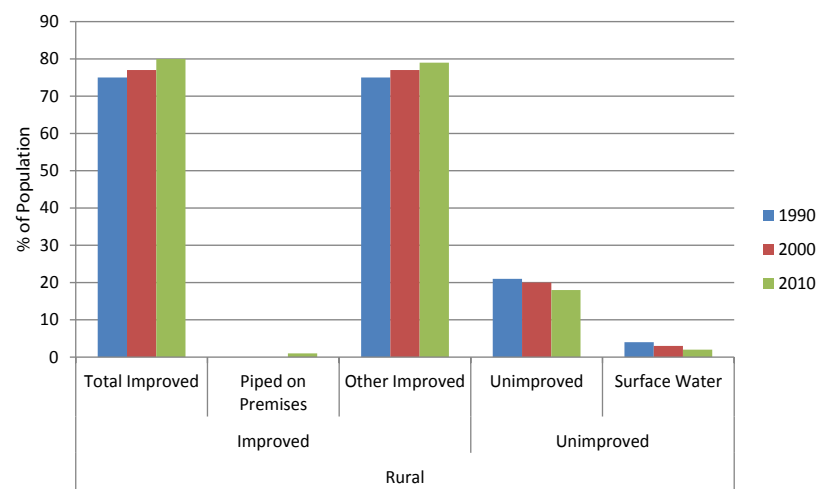

Figure 3: Status of safe drinking water from 1990 to 2010 in rural area of Bangladesh.

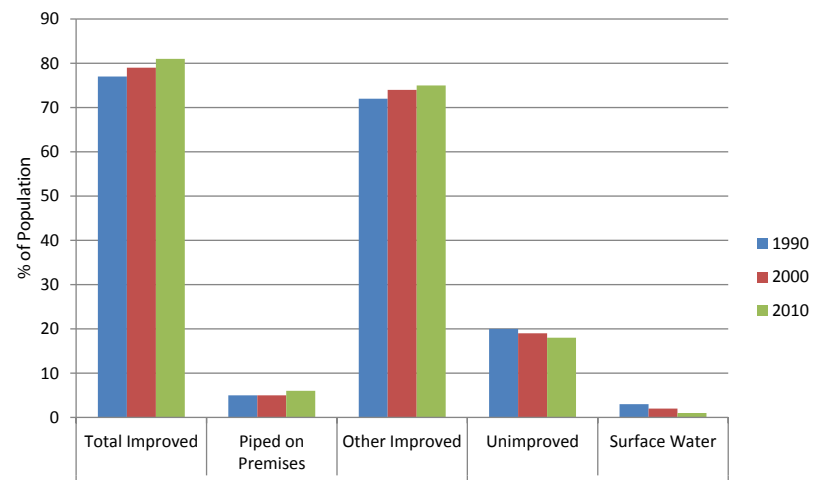

Figure 4: National safe drinking water from 1990 to 2010 of Bangladesh. for arsenic mitigation in the drinking water, health and agriculture sectors. Since 2004, knowledge of arsenic contamination its risks and mitigation options, has improved significantly. Thus, reflecting a widely felt perception amongst stakeholders, the Local Government Division of the MLGRD\&C requested a review of IPAM 2004.

Five other mitigation approaches promoted by the NPAM have had a limited impact, each reaching $<1 \%$ of the population at risk. The early record of arsenic removal from groundwater by adsorption and/or coprecipitation is mixed. Failures have arisen from inadequate removal due to the challenging composition of the groundwater, logistical difficulties in ensuring proper maintenance, and inconvenience to the users [11-13]. Since four arsenic-removal technologies have been provisionally approved for marketing, however, treatment may become more widespread. Dug wells are used by thousands of villagers. Although the shallowest aquifers tapped by these wells are typically low in arsenic, a full-scale return to this traditional technology is hampered by concerns regarding the microbial quality of the water and the need for regular maintenance (IPAM, 2009).

Since the adoption of IPAM 2004, various activities have taken place in the country. The screening of 5 million wells in 272 Upazilas was the most remarkable achievement. Although there are some doubts about the quality of the field kits, in particular their precision in waters close to $50 \mathrm{ppb}$, the program was very valuable in identifying the most severely affected areas, populations, and prioritizing mitigation efforts. Overall progress in mitigation has not kept pace with the magnitude of the arsenic problem. Major shortcomings in IPAM 2004 were (i) the lack of quantitative time-bound targets, and (ii) the weak monitoring and evaluation framework for projects (IPAM, 2009).

The IPAM 2004 was reviewed at 2009. At the centre of IPAM 2009 are simple non-excludable targets that create incentives for LGIs and water service providers to work together to mitigate water quality risks. Targets will exist at local level to guide LGIs, and at national level to prioritize the population at risk, where and when, and hence to ensure adequate budget provision. This will be supported by improved systems for planning, monitoring and reporting. This will also require a major improvement in data management, and a commitment to share information across ministerial, and government and non-governmental, boundaries. Coordination will be simplified by clarifying the roles of the arsenic committees at each level.

Supply of As free, safe drinking water remains the most crucial issue in the As mitigation program. The geohydrological situation of Bangladesh varies from area to area. Similarly, soil types and water chemistry vary from region to region. Water chemistry is particularly important in developing As removal technologies because performance of a number of As removal technologies depends on water quality, especially $\mathrm{pH}$. For immediate safe drinking water supply, short-term options such as As removal technologies can be used. However, to solve the problem permanently, a long-term solution needs to be adopted. In an area where the proportion of TWs having elevated As concentrations is not high, people can often collect water from the nearby As-safe TWs. Sludge disposal generated from the As removal technologies are an issue of worries. If not disposed of properly, it may have the potential to pollute the surrounding safe ground water again or create a new environmental hazard.

It involved much effort and time to convince people to shift from using relatively polluted surface water to safe ground water. Now people have a strong preference for TW and it would not be easy to shift these large populations from the TW option again. The situation 
might be worse in areas where no symptoms of arsenic toxicity have become visible even after a long duration of As exposure. Therefore, a strong Behavioral Change Communication (BCC) component should be added with the water supply programs in order to bring positive changes in the behavior of the users' population.

Bangladesh has reinforced the importance of using organizations and systems that are already in place in the affected area. When a rapid response to a health emergency is needed, it is not the time to reorganize or implement completely new systems. Rather, it is the time to take advantage of existing governmental and nongovernmental organizations, which already have contacts in the field and can thus respond quickly. The rapidity of the response is crucial-the longer the exposure continues, the greater the likelihood of disease.

\section{Alternative Option for Arsenic Free Drinking Water}

\section{Pond sand filter (PSF)}

In the hilly areas or in the coastal belt of Bangladesh, where salinity in the shallow groundwater is reported to be a severe problem, the Department of Public Health Engineering (DPHE) and UNICEF have installed slow sand filtration units linked. Hand pumps are used to deliver pond water to the units, which are called Pond Sand Filters (PSF). In this slow sand filtration system a bed of fine sand is used through which the water slowly percolates downward, resulting in the removal of pathogens through a combination of physical and biological processes. One PSF can supply the daily requirement of drinking and cooking water for about 40-60 families with a cost of about US\$ 600 . Once trained, masons with locally available materials can construct PSF. There is no chemical treatment involved in this process and little effect on the environment.

\section{Prospect and constrain of Pond Sand Filter (PSF)}

The greatest challenge for this option is to find suitable ponds which are perennial, free from pisciculture, and protected from using for bathing and washing clothes, cattle, etc. It has been reported that many of the PSFs constructed in the past in other arsenic affected areas where BRAC is providing As mitigation options, are now abundant as the owners' of the ponds restarted commercial fishing activities (BRAC 2000). Most ponds are privately owned and therefore, villagers have little to say about changing owners' decision about restarting commercial fishing activities in spite of having formal agreement with the community that they will reserve the ponds for drinking water use only. However, there is potential that PSFs could be one sustainable alternative to the arsenic problem in some areas.

\section{Rain Water Harvester (RWH)}

Rainwater harvesting is utilized in many parts of the world to meet the demand for drinking water. There is a long-established tradition of rainwater collection in some parts of Bangladesh, where shallow groundwater water has elevated salinity. Although the potential for rainwater harvesting is good in some areas of Bangladesh, the amount of rainfall varies widely across the country. Rashid [14] shows that mean annual precipitation ranges from $1,400 \mathrm{~mm}$ (about 55 inches) along the country's central western border to more than $5,000 \mathrm{~mm}$ ( 200 inches) in the far northeast. The wet months are mid-June to late September and the dry period is from January to April. About $80 \%$ of the annual precipitation occurs in the monsoon period. Rainfall patterns were also confirmed with local communities in order to ascertain the feasibility of RWH, and alternatives and parallel use of other options should be considered for total coliform and faecal coliform bacteria to assess the safety level of the RWH water for drinking.

\section{Commonly used Recent Practiced Filters}

\section{Bishuddhya filter}

This non-chemical based filter is basically designed to remove pathogen load from surface water. The filtration and purification technique used in this system is similar to PSF technology. Bishuddhya filters are relatively inexpensive and produced in Bangladesh.

\section{Three-kolshi or three-pitcher filter}

The three-pitcher filter is based on an indigenous method of filtration, which has been used in Bangladesh for ages. Traditionally, two local clay pitchers (called kolshi) are used to filter water [15].

\section{Activated alumina filter (ALCAN filter)}

The basic principle of this system is adsorption of As by activated alumina. In this filter the raw water passes upward through the activated alumina media and the treated water becomes As free. Activated alumina is formed by the thermal dehydration $\left(250^{\circ} \mathrm{C}\right.$ to $\left.1150^{\circ} \mathrm{C}\right)$ of an aluminum hydroxide such as, gibbsite, bayerite, etc. Its principle characteristic is high surface area $\left(>200 \mathrm{~m}^{2} / \mathrm{g}\right)$ and associated porosity. The term activated refers to the capacity of the alumina to enter into adsorption and/or catalytic reactions, and is determined largely by such variables as crystal structure, pore size and distribution, and the chemical nature of the surface [16-54].

\section{Conclusions}

Contamination of drinking-water with arsenic illustrates the difficulties of community based interventions. It is likely that a single visit to a village, during which the water is tested and the nearest well painted red, would not have a long-term impact on the behavior of members of the community, particularly if none of the villagers has any signs of arsenic-caused disease. Habits are difficult to break, one visit will not be convincing when the villagers look at the clear, clean water.

Follow-up monitoring and education are integral to sustaining the impact of the first intervention and safeguard the population's health. Long-term solutions would likely have to be tailored to local environments, and it is counterproductive to defer immediate action until the long-term alternatives are completely designed. The cause of arsenicosis is clear and continuing exposure increases the risk of nonfatal outcomes and death, the disease could be eradicated at relatively low cost. Finally it could be said that fair follow of funding, continuous monitoring and evaluation of plans and strategies are the principle components to ensure sustainability for the safe drinking water in Bangladesh. The article would be helpful much in that direction.

\section{References}

1. Adel MM (2000) Arsenification: Searching for an Alternative Theory. Daily Star of Bangladesh.

2. Akram S (1997) Arsenic Problem. Daily Sangbad of Bangladesh.

3. Anwarul Islam AS, Haque MH, Mazumder MH (1998) Arsenic Problem and its Investigations. Engineering News 5: 16-20.

4. Ahmed KM, Bhattacharya P, Hasan MA, Akhter SH, Alam SMM et al., (2004) Arsenic enrichment in groundwater of the alluvial aquifers in Bangladesh: An overview. Appl Geochem 19: 181-200.

5. Ahmed MF, Shamsuddin SAJ, Mahmud SG, Rashid H, Deere D, et al. (2005) Risk Assessment of Arsenic Mitigation Options (RAAMO). Dhaka: Arsenic Policy Support Unit, Dhaka. 
6. Akhtaruzzaman M, Khan NI, Sheikh NI (2013) Nutrition, Health and Demographic Survey of Bangladesh-A Preliminary Report. Institute of Nutrition and Food Science, University of Dhaka Dhaka-1000, Bangladesh.

7. Bhattacharya $P$, Chatterjee D, Jacks G (1997) Occurrence of arsenic contaminated groundwater in alluvial aquifers from Delta Plains, Eastern India: Options for safe drinking water supply. Int Jour Water Res Management 13 79-92.

8. Bhattacharya P, Frisbie SH, Smith E, Naidu R, Jacks G, et al., (2002) Arsenic in the Environment: A Global Perspective. In: B. Sarkar (ed) Handbook of Heavy Metals in the Environment Marcell Dekker Inc., York, pp. 147-215

9. Bhattacharya P, Welch AH, Ahmed KM, Jacks G, Naidu R (2004) Arsenic in Groundwater of Sedimentary Aquifers. Appl Geochem 19: 163-167.

10. BRAC (2000) Combating a deadly menace-Early Experience with A Community-based Arsenic Mitigation Project in Rural Bangladesh. Res Monogr Ser 16: 1-116.

11. Begum ZR, Karim MM (2000) Arsenic Groundwater Contamination of Bangladesh: Community Participation in Groundwater Resources Management. Proceedings of $93^{\text {rd }}$ Annual Meeting of Air and Waste Management Association: Salt Lake, Utah, USA: 1-10.

12. Bridge TE, Husain MT (1999a) When did the Groundwater Arsenic Poisoning in Bangladesh Begin? News from Bangladesh.

13. Bridge TE, Husain MT (1999b) The Increased Draw Down and Recharge in Groundwater Aquifers and their Relationship to the Arsenic Problem in Bangladesh.

14. Bridge TE, Husain MT (2000a) Clean Healthy Water for Bangladesh-an Emergency Supply is desperately needed to protect the People from the Arsenic Disaster.

15. Bridge TE, Husain MT (2000b) Groundwater Arsenic Poisoning and a Solution to the Arsenic Disaster in Bangladesh. Presented at the ICBEN conference at Dhaka, Bangladesh. Daily Star of Bangladesh.

16. Arsenic contamination of groundwater in Bangladesh (2001) BGS Technical Report WC/001/19. British Geological Survey, Keyworth, UK.

17. Chowdhury AMR, Jakariya M (1999) Testing of Water for Arsenic in Bangladesh Science 284: 1621

18. Hopenhayn-Rich C, Browning SR, Hertz-Picciotto I, Ferreccio C, Peralta C, et al. (2000) Chronic arsenic exposure and risk of infant mortality in two areas of Chile. Environmental Health Perspectives 108: 667-673.

19. DPHE and UNICEF (1988-93) Water Supply and Sanitation Project Implementation Guideline and Specification for the Rural Areas of the Coastal Region.

20. DPHE/BGS/DFID (2000) Groundwater Studies of Arsenic Contamination in Bangladesh, Final Report, Dhaka.

21. Government of Bangladesh (2004) National Policy for Arsenic Mitigation and Implementation Plan for Arsenic Mitigation in Bangladesh. Dhaka: Government of Bangladesh (GOB).

22. Heikens A (2006) Arsenic Contamination of Irrigation Water, Soil and Crops in Bangladesh: Risk Implications for Sustainable Agriculture and Food Safety in Asia. United Nations Food and Agriculture Organization. Regional Office for Asia and the Pacific Publication 2006/20.

23. Hanchett $S$ (2006) Social aspects of the arsenic contamination of drinking water: A review of knowledge and practice in Bangladesh and West Bengal. In APSU Selected papers on the social aspects of arsenic and arsenic mitigation in Bangladesh. Dhaka, Bangladesh: Arsenic Policy Support unit: 1-51.

24. Hossain Z, Quaiyum M, Jakariya M (2003) Using materials for mass communication: experiences of an arsenic mitigation project in Bangladesh. Bangladesh Journal of Mass Communication and Publishing 2.

25. Hossain A, Rabbi MF, Abid AR, Sadek S (2000) Arsenic Problem in Groundwater, a Growing Threat to Public Health in Bangladesh: An Overall Perspective and Management Modelling Approach. K. Sato and Y. Iwasa, eds. Proceedings of the International Symposium 2000 on Groundwater. 7-10 May 2000: Saitama, Japan.

26. Howard G, Ahmed MF, Teunis P, Mahmud SG, Davison A, et al. (2007) Disease burden estimation to support policy decision-making and research prioritization for arsenic mitigation. J Water Health 5: 67-81.
27. Howard G, Ahmed MF, Shamsuddin AJ, Mahmud SG, Deere D (2006) Risk assessment of arsenic mitigation options in Bangladesh. J Health Pop Nutrit 24: 346-355.

28. Jahan MS, Rasul MT (2010) Quality of Ground and Surface Water of Rajshah City Area for Sustainable Drinking Water Source. Journal of Scientific Research 2: $577-584$.

29. Jakariya M, Chowdhury AMR, Hossain MZ, Rahman M (2003) Management of chronic arsenicosis patients in Bangladesh. Tropical Doctor 33: 251-252.

30. Jakariya M, Chowdhury AMR, Hossain Z, Rahman M, Sarker Q, et al. (2003) Sustainable community-based safe water options to mitigate the Bangladesh arsenic catastrophe-An experience from two upazilas. Current Science 85 141-146.

31. JICA/DPHE (2002) The groundwater development of deeper aquifers safe drinking water supply to arsenic affected areas in western Bangladesh. Final report, Dhaka.

32. Khan AW, Ahmad SKA (1997) Arsenic in drinking water: Health effects and management. A training manual. Department of Occupational and Public Health. National Institute of Preventive and Social Medicine (NIPSOM). Dhaka.

33. Khalequzzaman M (1999) Comments on Arsenic Study in Bangladesh. Daily Star of Bangladesh.

34. Kamal MR, Karim MM (2000) GIS Application for Monitoring Arsenic Groundwater Contamination Exposures in Bangladesh.

35. Karim MM (2000a) Arsenic in Groundwater and Health Problems in Bangladesh Journal of Water Research 34: 304-310.

36. Karim MM (2000b) Arsenic Exposure Modeling and Risk Assessment in Bangladesh using Geographic Information System. The Second International Health Geographic Conference. Washington DC, USA

37. Karim MA, Komori Y, Alam M (1997) Subsurface Arsenic Occurrence and Depth of Contamination in Bangladesh. Journal of Environmental Chemistry 7: 783-792.

38. Klump S, Kipfer R, Cirpka OA, Harvey CF, Brennwald MS et al. (2006) Groundwater dynamics and arsenic mobilization in Bangladesh assessed using noble gases and tritium. Environ Sci Technol 40: 243-250.

39. Meharg AA, Rahman MM (2003) Arsenic contamination of Bangladesh paddy field soils: Implications for rice contribution to arsenic consumption. Environ Sci Technol 37: 229-234.

40. Milton AH, Smith W, Dear $\mathrm{K}, \mathrm{Ng} \mathrm{J}$, Sim M, et al. (2006) A randomised intervention trial to assess two arsenic mitigation options in Bangladesh. Epidemiology 17: S219.

41. Nickson R, McArther J, Burgess W, Ahmed KM, Ravenscroft P (1998) Arsenic Poisoning of Bangladesh Groundwater. Nature 395.

42. Nickson RT, McArther JM, Ravenscroft P, Burgess WG, Ahmed KM (1999) Mechanism of Arsenic Release to Groundwater, Bangladesh and West Bengal. Journal of Applied Geochemistry 15: 403-413.

43. National Institute of Population Research and Training (NIPORT) Mitra and Associates, and ICF International (2013) Bangladesh Demographic and Health Survey 2011. NIPORT, Mitra and Associates, and ICF International, Dhaka, Bangladesh and Calverton, Maryland, USA

44. NMIDP (National Minor Irrigation Development Project) (1998) National Mino Irrigation Census 1996/97Sir William Halcrow and Partners Ltd. and DHV Consultants BV, Dhaka, Bangladesh.

45. Nickson RT, McArthur JM, Ravenscroft P, Burgess WG, Ahmed KM (2000) Mechanism of arsenic release to groundwater, Bangladesh and West Bengal. Appl Geochem 15: 403-413.

46. Rahman MM, Chowdhury UK, Mukherjee SC, Mondal BK, Paul K, et al. (2001) Chronic arsenic toxicity in Bangladesh and West Bengal, India-a review and commentary. J Toxicol Clin Toxicol 39: 683-700.

47. Rahman MM, Mukherjee D, Sengupta MK, Chowdhury UK, Lodh D, et al. (2002) Effectiveness and reliability of arsenic field testing kits: Are the million dollar screening projects effective or not? Env Sci Technol 36: 5385-5394.

48. Rashid H (1977) The Geography of Bangladesh. University Press Limited Dhaka. Smedley PL, Kinniburgh DG (2002) A review of the source, behavior and distribution of arsenic in natural waters. Appl Geochem 17: 517-568. 
Citation: Das K, Roy D, Mostafa MG (2015) Sustainable Management for Arsenic (As) Free Safe Drinking Water in Bangladesh: A Review. J Pet Environ Biotechnol 6: 228. doi:10.4172/2157-7463.1000228

Page 6 of 6

49. Ravenscroft P, Burgess WG, Ahmed KM, Burren M, Perrin J (2005) Arsenic in groundwater of the Bengal Basin, Bangladesh: Distribution, field relations, and hydrogeological setting. Hydrogeol J 13: 727-751.

50. Smith AH, Lingas EO, Rahman M (2000) Contamination of drinking-water by arsenic in Bangladesh: a public health emergency. Bull. World Health Organization 78: 1093-1103.

51. Sultana F (2006) Gender concerns in arsenic mitigation in Bangladesh: Trends and challenges. In: APSU Selected papers on the social aspects of arsenic and arsenic mitigation in Bangladesh. Arsenic Policy Support Unit 53-84, Dhaka, Bangladesh.
52. SOES-DCH (2000) Groundwater Arsenic Contamination in Bangladesh A. Summary of 239 days field survey from August 1995 to February 2000 B. Twenty-seven day's detailed field survey information from April 1999 to February 2000. School of Environmental Studies, Jadavpur University, Calcutta 700032, India and Dhaka Community Hospital, Dhaka 1217, Bangladesh.

53. WHO (2001) Arsenic in drinking water: Fact Sheet 210. Geneva

54. WHO/UNICEF (2012) Joint Monitoring Programme for Water Supply and Sanitation. Progress on Drinking Water and Sanitation: 2012. 